\title{
EFFECT OF USING (Moringa oleifera) SEED MEAL ON PERFORMANCE OF GROWING QUAIL BIRDS
}

\author{
Mohamed M. El-Kashef ${ }^{*}$, M.A. AbdEIGhaffar ${ }^{1}$, H.A. Khaliil ${ }^{2}$ and A.M. Ali ${ }^{1}$ \\ 1. Dept. Anim. and Poult. Prod., Fac. Environ. Agric. Sci., Arish Univ., Egypt. \\ 2. Dept. Anim. Prod., Fac. Agric. Suez Canal Univ., Egypt.
}

\begin{abstract}
The aim of the study was to investigate the effect of feeding quail chicks on diets containing different levels of Moringa oleifera Seed meal (MOSM) on growth performance, carcass quality and blood constituents. A total of 180 seven days, unsexed quail chicks were randomly divided into four experimental groups. Each group was further subdivided into 3 replicates, 15 chicks per each. Four levels of MOSM (0.0, 0.2, 0.4 and $0.6 \%)$ were fed during the experimental period for 6 weeks duration. The results showed that, birds fed on $0.2 \%$ MOSM gained significantly higher body weight and body weight gain than birds fed the control diet. The lowest feed consumption $(\mathrm{P} \leq 0.01)$, best feed conversion ratio were obtained by using $0.4 \%$ MOSM compared to control group and other treatments MOSM. Dressing, liver, heart, gizzard and giblets significantly increased by feeding quail birds on levels 0.2 , and $0.4 \%$ MOSM respectively compared to the control group and those fed $0.6 \%$ MOSM. Group fed diet supplemented with $0.2 \%$ MOSM significantly $(\mathrm{P} \leq 0.05)$ had the higher total edible parts compared with control group and other treatment groups. Birds fed diet without any MOSM insignificantly had higher total protein, albumin and $\mathrm{A} / \mathrm{G}$ ratio compared to those fed diet supplemented with 0.2, 0.4 MOSM treatment. Birds fed diet Supplemented with 0.6\% MOSM lead to significant increasing in the blood glucose as compared to control and other treatments. Blood cholesterol, ALT and AST had lower level in all treatments compared to control group. Inclusion, the present results showed that the use of MOSM at levels of 0.2 or $0.4 \%$ improved quail performance and economic efficiency.
\end{abstract}

Key words: Quail, Moringa oleifera seed, performance, blood and carcass.

\section{INTRODUCTION}

The availability and price of concentrates, in particular of protein sources, are a serious problem for poultry producers, especially for small farms stakeholders. Consequently, there is a need for alternative ingredients with high protein content and balanced amino acids profile, and with a suitable cost. Plants leaf meal, forage trees, saltbush and shrubs are good and cheap sources of protein (Dey and De, 2013, Mahmud et al., 2016). One of these potential tree forages is Moringa oleifera Lam (syns. Moringa pterygosperm, family
Moringaceae), which grows throughout the tropics (Debela and Tolera, 2013). Moringa oleifera is a plant possess multiple advantages. Different parts of the tree (leaves, fruits, immature pods and flowers) are edibles and entered in traditional diets in many tropics and subtropics countries (Anhwange et al., 2004 ).

Moringa oleifera seeds have been reported as good sources of the main feed ingredients including fats, proteins and minerals (Compaoré et al., 2011). The major saturated fatty acids present in seeds are palmitic, stearic, arachidic and benic acids.

\footnotetext{
* Corresponding author: Tel.: +201069246609

E-mail address: melkashef82@yahoo.com
} 
Oleic acid is the main unsaturated fatty acid whose high concentration is desirable in terms of nutrition and stability during cooking and frying. Recent studies indicated that moringa seed meal has been successfully used in poultry diets (Abbas and Ahmed, 2012, Olaniyan, 2012, Ochi et al., 2015, Mousa et al., 2016 Riry Shata et al., 2016) who reported that feeding broilers on Moringa oleifera seed increased live body weight, body weight gain, feed consumption and improve feed conversion ratio. This study was, therefore, conducted to determine the effect of moringa seed meal supplementation on growth performance, carcass characteristics and economic efficiency of quail birds.

\section{MATERIALS AND METHODS}

The study was carried out at the farm of the Department of Animal and Poultry Production, Faculty of Environmental Agricultural Sciences, Arish University, El Arish, North Sinai, Egypt.

A total number of 180 unsexed birds of Japanese quail-7 days old- are having nearly equal live weights (33g) were distributed into four groups. Each group was comprised of 45 birds which were subdivided into three replicates of 15 birds each. Birds were fed on $24 \% \quad \mathrm{CP}$ and $2900 \mathrm{Kcal}$. Dietary treatments were designed to contain 0.0 (control), 0.20, 0.40 and $0.60 \%$ Moringa oleifera seed meal (MOSM). All diets met the nutrient requirements of quail as set out by National Research Council (NRC) (1994). Table (1) represents the ingredients composition of the experimental diets. All birds received feed and water ad libitum. Body weight, and feed consumption were recorded biweekly and average body weight gains; feed conversion ratio were calculated.

At 42 days of age, three birds from each treatment having live body weight around the average of treatment were selected and slaughtered to obtain the carcass; giblets (gizzard, liver and heart). Blood samples were taken to determine serum content of total protein, albumin, globulin, glucose, total lipid, cholesterol, low density lipoprotein (LDL), high density lipoprotein (HDL) and liver enzymatic activity (AST and ALT) using commercial kits

The prevailing market prices of ingredients and Moringa oleifera seeds used during the period of the study were used for the economic appraisal of the feeds. Economical efficiency is defined as the net revenue per unit feed cost calculated from input, output analysis as described by Asar et al. (2010).

The economics of efficiency was calculated by the following:

Feed cost $=$ number of $\mathrm{kg}$ feed per quail $\times$ price of $\mathrm{kg}$ feed.

Selling revenue $=$ body weight gain per quail $\times$ price of $\mathrm{kg}$ for live body weight.

Net revenue $=$ difference between selling revenue and feed cost.

E.EF $($ Economic efficiency $)=($ net revenue/ feed cost $) \times 100$.

R.E.E (Relative economic efficiency), assuming control treatment $=100 \%$.

The obtained data was statistically analyzed using the general linear model procedure described in SAS User's Guide (SAS., 2004). Differences among means were tested using Duncan's multiple range test (Duncan, 1955).

\section{RESULTS AND DISCUSSION}

\section{Growth Performance}

Effect of dietary Moringa oleifera seed meal (MOSM) levels (0.0, 0.2, 0.4 and $0.6 \%$ ) on live body weight (BW) and body weight gain (BWG) of quail chicks are summarized in Table 2.

The initial live body weights at 7 days of age for all treatments were nearly $33 \mathrm{~g}$ with no significant differences between them. This may create suitable condition to appraise the effect of dietary treatments during the subsequent experimental periods. 
SINAI Journal of Applied Sciences (ISSN: 2314-6079) Vol. (6) Is. (3), Dec. 2017

Table (1): The composition and calculated analysis of quail diets.

\begin{tabular}{|c|c|c|c|c|}
\hline \multirow{2}{*}{ Ingredients (\%) } & \multirow[b]{2}{*}{ Control } & \multicolumn{3}{|c|}{ Moringa oleifera Seeds meal (\%) } \\
\hline & & 0.2 & 0.4 & 0.6 \\
\hline Yellow corn & 55.78 & 55.88 & 55.99 & 56.10 \\
\hline Soybean & 33.67 & 33.51 & 33.35 & 33.18 \\
\hline Corn gluten & 7.3 & 7.3 & 7.3 & 7.3 \\
\hline Di-calcium phosphate & 0.8 & 0.8 & 0.8 & 0.8 \\
\hline Limestone & 1.58 & 1.44 & 1.29 & 1.16 \\
\hline Salt & 0.35 & 0.35 & 0.35 & 0.34 \\
\hline (Vit. \& Min.)Premix* & 0.3 & 0.3 & 0.3 & 0.3 \\
\hline DL-Methionine & 0.11 & 0.11 & 0.11 & 0.11 \\
\hline L-Lysine & 0.11 & 0.11 & 0.11 & 0.11 \\
\hline MOSM & - & 0.2 & 0.4 & 0.6 \\
\hline Total & 100 & 100 & 100 & 100 \\
\hline \multicolumn{5}{|c|}{ Calculated analyses (\%) } \\
\hline Crude protein (\%) & 24 & 24 & 24 & 24 \\
\hline ME Kcal/Kg & 2900 & 2900 & 2900 & 2900 \\
\hline Calcium & 0.9 & 0.89 & 0.84 & 0.8 \\
\hline AV. Phosphorus & 0.4 & 0.45 & 0.43 & 0.4 \\
\hline L. Lysine & 1.23 & 1.23 & 1.24 & 1.22 \\
\hline DL. Methionine & 0.46 & 0.46 & 0.46 & 0.46 \\
\hline
\end{tabular}

Table (2): Effect of dietary Moringa oleifera seeds meal on growth performance of Japanese quail at of 42 days old.

\begin{tabular}{ccccc}
\hline \multirow{2}{*}{ Trait } & \multirow{2}{*}{ Control } & \multicolumn{3}{c}{ Moringa oleifera Seeds meal (\%) } \\
\cline { 3 - 5 } & & $\mathbf{0 . 2}$ & $\mathbf{0 . 4}$ & $\mathbf{0 . 6}$ \\
\hline Initial body weight (g) & $33.00 \mathrm{a} \pm 0.00$ & $33.00 \mathrm{a} \pm 0.00$ & $33.00 \mathrm{a} \pm 0.00$ & $33.00 \mathrm{a} \pm 0.00$ \\
Final body weight $(\mathbf{g})$ & $253.65 \mathrm{c} \pm 1.08$ & $278.71 \mathrm{a} \pm 0.71$ & $274.18 \mathrm{~b} \pm 0.82$ & $245.41 \mathrm{~d} \pm 0.73$ \\
Body weight gain $(\mathbf{g})$ & $246.65 \mathrm{c} \pm 1.08$ & $271.71 \mathrm{a} \pm 0.71$ & $267.18 \mathrm{~b} \pm 0.82$ & $238.41 \mathrm{~d} \pm 0.73$ \\
Total feed intake (g) & $554.16 \mathrm{~b} \pm 5.86$ & $598.21 \mathrm{a} \pm 3.06$ & $567.10 \mathrm{~b} \pm 2.87$ & $529.12 \mathrm{c} \pm 4.68$ \\
Feed conversion $(\mathbf{g} / \mathbf{g})$ & $2.25 \mathrm{a} \pm 0.02$ & $2.20 \mathrm{a} \pm 0.01$ & $2.12 \mathrm{~b} \pm 0.01$ & $2.22 \mathrm{a} \pm 0.03$ \\
\hline
\end{tabular}

a,b,c Means in the same row with different superscripts are significantly different $(p<0.05)$. 
Results showed that birds fed MOSM level $0.2 \%$ recorded significantly $(\mathrm{P} \leq 0.05)$ higher $\mathrm{BW}, \mathrm{BWG}$ and feed intake values compared to control group and other treatments during the period from $7-42$ days. Addition of MOSM up to $0.6 \%$ to the diet significantly $(\mathrm{P}<0.05)$ lowered $\mathrm{BW}$ and BWG compared to control group and other treatments. The improved weight gain of birds fed on Moringa oleifera seed meal compared to control group may be due to Moringa oleifera seeds are good source of fat, protein, antioxidants and minerals (Compaoré et al., 2011). These results are in agreement with Abbas and Ahmed (2012) who used Moringa oleifera seed powder at levels of $0.37,0.75$ or $1.5 \%$ in broilers diets and observed that the level of $0.37 \%$ increased live body weight compared to control

Also, Ochi et al. (2015) mentioned that the inclusion of Moringa oleifera seed powder (MOSP) at levels $0.5,1$ and $2 \%$ in the diet of the broilers significantly $(\mathrm{P} \leq 0.05)$ enhanced their body weight, body weight gain and feed intake. On the other hand, Mousa et al. (2016) used 0.25, 0.50 and $0.75 \%$ germinated Moringa oleifera seed (GMOS) in the quail chicks' diet and observed that $0.75 \%$ MOSP significant increased $(\mathrm{P} \leq 0.05)$ body weight and body weight gain. Also, Olaniyan (2012) reported that feeding 10\% Moringa seed to broilers increased live body weight than the control diet. On the other hand Atuahene et al. (2010) reported insignificant effect of diets containing Moringa leaf meal at 0 , 2.5, 5 and $7.5 \%$ levels on body weight gain and feed intake of broiler chickens. For feed conversion, data in Table 2 indicted that the birds fed diet supplemented with $0.4 \%$ Moringa oleifera seeds meal had the best feed conversion ratio compared with control and other treatments.

This improvement in body weight gain and FCR may be attributed to rich content of nutrients in germinated Moringa oleifera seed (Toye et al., 2013) and anti-microbial properties of Moringa (Fahey et al., 2001). These results are in agreement with EIDeeb et al. (2014) who observed that level $2 \%$ in quail diets improved feed conversion compared to control group.

However, Shehta et al. (2016) found that quail birds fed diet supplemented with 5\% Moringa oleifera seed meal (MOSM) had the best feed conversion compared with control group. On contrary, Makanjuola et al. (2014) observed no effect on FCR when broilers were fed 0.2, 0.4 and 0.6\% MOLM. While birds fed control, 0.2 and $0.6 \%$ had higher feed intake than birds fed $0.4 \%$.Also, Paguia et al. (2014) found that using 0.20 , $0.30,0.40$ and $0.50 \%$ MOLM in broiler diets did not $(\mathrm{P}<0.05) \quad$ significantly influence the FCR values.

\section{Carcass Characteristics:}

Statistical analyses of carcass yield in different groups are showen in Table 3. The birds fed diet supplemented with 0.2 or $0.4 \%$ Moringa oleifera seeds meal significantly $(\mathrm{P} \leq 0.05)$ increased dressing $\%$, liver, heart, gizzard and giblets compared with control and group fed 0.6\% Moringa oleifera seeds.

However group fed diet supplemented with $0.2 \%$ (MOSM) significantly $(\mathrm{P} \leq 0.05)$ had the higher total edible parts compared with control group and other treatment group. Birds fed diet supplemented with 0.4 or $0.6 \%$ Moringa oleifera seeds meal significantly $(\mathrm{P} \leq 0.05)$ had higher head weight compared with control and group fed $0.2 \%$ Moringa oleifera seeds. These results may be due to antioxidant activities of some components of Moringa oleifera like vitamins $C$ and $E$ (Rocha et al., 2010) and phenols especially flavonoids (Diallo $\boldsymbol{e t}$ al., 2009).

These results are in agreement with Ochi et al. (2015) and Mousa et al. (2016) who found that germinated moringa seed meal supplementation increased gizzard weight 
SINAI Journal of Applied Sciences (ISSN: 2314-6079) Vol. (6) Is. (3), Dec. 2017

Table (3): Effect of dietary Moringa oleifera seeds meal on carcass characteristics of quail at 42 days old.

\begin{tabular}{|c|c|c|c|c|}
\hline \multirow{2}{*}{ Traits } & \multirow[b]{2}{*}{ Control } & \multicolumn{3}{|c|}{ Moringa oleifera Seeds meal (\%) } \\
\hline & & 0.2 & 0.4 & 0.6 \\
\hline Live weight(g) & $250.00 \mathrm{~b} \pm 0.97$ & $279.89 \mathrm{a} \pm 1.03$ & $277.89 \mathrm{a} \pm 1.06$ & $245.89 \mathrm{c} \pm 1.57$ \\
\hline Dressing (\%) & $73.33 \mathrm{c} \pm 0.19$ & $78.20 \mathrm{a} \pm 0.08$ & $77.73 \mathrm{a} \pm 0.36$ & $73.24 \mathrm{~b} \pm 0.19$ \\
\hline Head (g) & $10.08 \mathrm{~b} \pm 0.01$ & $10.06 \mathrm{~b} \pm 0.10$ & $10.47 \mathrm{a} \pm 0.02$ & $10.34 \mathrm{a} \pm 0.02$ \\
\hline Liver (g) & $5.48 \mathrm{~b} \pm 0.03$ & $6.54 \mathrm{a} \pm 0.14$ & $6.37 \mathrm{a} \pm 0.14$ & $5.29 \mathrm{~b} \pm 0.02$ \\
\hline Heart (g) & $2.16 \mathrm{~b} \pm 0.06$ & $2.65 \mathrm{a} \pm 0.03$ & $2.48 b \pm 0.03$ & $2.18 \mathrm{c} \pm 0.02$ \\
\hline Gizzard (g) & $4.20 \mathrm{~b} \pm 0.03$ & $5.22 \mathrm{a} \pm 0.14$ & $5.05 \mathrm{a} \pm 0.14$ & $3.97 \mathrm{~b} \pm 0.02$ \\
\hline Giblets *(g) & $11.84 \mathrm{~b} \pm 0.04$ & $14.41 \mathrm{a} \pm 0.26$ & $13.90 \mathrm{a} \pm 0.26$ & $11.45 \mathrm{~b} \pm 0.06$ \\
\hline Total edible parts** (g) & $195.17 \mathrm{c} \pm 0.72$ & $233.30 \mathrm{a} \pm 1.06$ & $229.90 \mathrm{~b} \pm 0.95$ & $191.56 \mathrm{~d} \pm 1.41$ \\
\hline
\end{tabular}

a,b,c Means in the same row with different superscripts are significantly different $(\mathrm{p}<0.05)$.

$*$ giblets $=$ gizzard + liver + heart. $* *$ total edible parts $=$ dressing + giblets

of quail chickens. On the other hand, Shata et al. (2016) reported no improvements in dressing carcass and carcass organs except the gizzard due to inclusion of moringa seed meal in the diets of growing quail birds.

\section{Blood Constituents}

The results of the estimated blood plasma parameters at 42 days old as affected by dietary Moringa oleifera seed Meal (MOSM) are presented in Table 4 Results indicated that there was no significant effect in the average values of blood total lipids, LDL and HDL in chicks fed all levels of MOSM compared to control group.

Birds fed diet without any Moringa oleifera seed Meal supplementation insignificantly had higher total protein, albumin and $\mathrm{A} / \mathrm{G}$ ratio compared to those fed diet supplemented with 0.2 or 0.4 of MOSM treatment. However, Globulin was significantly increased in group $0.2,0.4$ and $0.6 \%$ MOSM as compared to control group. These results are in agreement with Mousa et al. (2016) who found that $\mathrm{A} / \mathrm{G}$ ratio was decreased in quail chicks fed different levels of germinated Moringa Oleifera seed (GMOS); 0.0, 0.2, 0.4 and $0.6 \%$ compared with control group. On contrary, Makanjuola et al. (2014) found that $0.2 \%, 0.4 \%$ and 0.6 MOLM did not influence the serum total protein, albumin and globulin.

Birds fed diet Supplemented with 0.6\% MOSM lead to significant increasing in the plasma glucose as compared to control and other treatments. Same result was obtained by Kout Elkloub et al. (2015) who found that quail birds fed diet supplementing with $0.4 \%$ and $0.6 \%$ Moringa oleifera leaf meal (MOLM) had high plasma glucose as compared to control and 0.2\% MOLM. On the other side Mousa et al. (2016) found no significant effect in plasma glucose when quail birds fed diet supplemented with 0.2 , 0.4 and $0.6 \%$ of germinated Moringa oleifera seed (GMOS).

Plasma cholesterol, ALT and AST were significantly $(\mathrm{P} \leq 0.05)$ reduced in all treatments compared to control. Similar results have been obtained by Mousa et al. (2016) who found significant $(\mathrm{P} \leq 0.01)$ 
Table (4): Effect of dietary Moringa oleifera seeds meal on some blood parameters of quail at 42 days old.

\begin{tabular}{ccccc}
\hline \multirow{2}{*}{ Traits } & \multirow{2}{*}{ Control } & $\mathbf{0 . 2}$ & $\mathbf{0 . 4}$ & $\mathbf{0 . 6}$ \\
\cline { 3 - 5 } & $4.73 \mathrm{a} \pm 0.07$ & $4.60 \mathrm{a} \pm 0.02$ & $4.47 \mathrm{ab} \pm 0.14$ & $4.28 \mathrm{~b} \pm 0.08$ \\
\hline T. protein(g/dl) & $2.59 \mathrm{~b} \pm 0.18$ & $2.99 \mathrm{a} \pm 0.11$ & $2.85 \mathrm{a} \pm 0.02$ & $2.95 \mathrm{a} \pm 0.10$ \\
\hline Albumin (A) (g/dl) & $1.71 \mathrm{a} \pm 0.14$ & $1.54 \mathrm{ab} \pm 0.02$ & $1.45 \mathrm{ab} \pm 0.12$ & $1.27 \mathrm{~b} \pm 0.12$ \\
Globulin (G) (g/dl) & $0.67 \mathrm{a} \pm 0.10$ & $0.52 \mathrm{ab} \pm 0.02$ & $0.51 \mathrm{ab} \pm 0.05$ & $0.43 \mathrm{~b} \pm 0.06$ \\
A/G ratio & $460.59 \mathrm{a} \pm 6.80$ & $481.36 \mathrm{a} \pm 3.55$ & $454.51 \mathrm{a} \pm 17.35$ & $434.97 \mathrm{a} \pm 22.23$ \\
T .lipids (mg/dl) & $155.37 \mathrm{~b} \pm 0.23$ & $153.98 \mathrm{~b} \pm 1.79$ & $163.57 \mathrm{ab} \pm 6.96$ & $171.65 \mathrm{a} \pm 5.14$ \\
Glucose (mg/dl) & $111.83 \mathrm{a} \pm 26.37$ & $69.91 \mathrm{a} \pm 7.88$ & $86.00 \mathrm{a} \pm 0.90$ & $76.48 \mathrm{a} \pm 7.75$ \\
LDL (mg/d) & $64.31 \mathrm{a} \pm 12.95$ & $77.69 \mathrm{a} \pm 11.24$ & $59.74 \mathrm{a} \pm 4.12$ & $75.36 \mathrm{a} \pm 7.61$ \\
HDL (mg/d) & $176.14 \mathrm{a} \pm 13.44$ & $147.61 \mathrm{~b} \pm 3.74$ & $145.74 \mathrm{~b} \pm 3.24$ & $151.84 \mathrm{~b} \pm 1.37$ \\
T. Cholesterol (mg/dl) & (mera Seeds meal (\%) \\
ALT U/ L & $44.28 \mathrm{a} \pm 1.08$ & $42.75 \mathrm{ab} \pm 0.30$ & $40.53 \mathrm{~b} \pm 0.63$ & $41.78 \mathrm{~b} \pm 0.78$ \\
AST U/L & $12.26 \mathrm{a} \pm 0.16$ & $11.78 \mathrm{ab} \pm 0.07$ & $11.44 \mathrm{~b} \pm 0.23$ & $11.58 \mathrm{~b} \pm 0.25$ \\
\hline
\end{tabular}

a,b,c Means in the same row with different superscripts are significantly different $(p<0.05)$.

reduction in total cholesterol and ALT in birds fed different levels from germinated Moringa Oleifera seed. Also, Durgesh et al. (2013) found significant $(\mathrm{P} \leq 0.01)$ reduction in total cholesterol in germinated Moringa oleifera seed supplemented birds

\section{Economic Evaluation}

Economic evaluation of feeding quail birds on moringa seeds meal supplementation is presented in Table 5 .

The best economic efficiency and relative economic efficiency were recorded for quail fed 0.4 followed with $0.2 \%$ of Moringa oleifera seed Meal. While the lowest value was recorded for birds fed diet supplemented with $0.6 \%$ of Moringa oleifera seed Meal. The same results were obtained by El-Badawi et al. (2014) who found that growing rabbit fed diet supplemented with $0.15 \%$ of moringa dry leaves had the highest economic efficiency and relative economic efficiency compared with the control group.

\section{Conclusion}

It could be concluded that the use of Moringa oleifera seed meal in quail diets improved performance, carcass characteristics and blood constituents without any adverse. The best level occurred by $0.20 \%$ Moringa oleifera seed meal in quail diets.

\section{REFERENCES}

Abbas, T.E. and Ahmed, M.E. (2012). Use of Moringa oleifera seeds in broilers diet and its effects on the performance and carcass characteristics. Int. J. Appl. Poult. Res., 1-4.

Anhwange, B.A.; Ajibola, V.O. and Oniye, S.J. (2004). Chemical studies of the seeds of Moringa oleifera (Lam.) and Detariummicrocarpum (Guill and Sperr). J. Biol. Sci., 4: 711-715.

Asar, M.A; Osman, M.; Yakout, H.M. and Safoat, A. (2010). Utilization of corn-cob meal and faba bean straw in growing rabbits diets and their effects on performance, digestibility and economical efficiency, Egypt. Poult. Sci. 30: 415-442. 
SINAI Journal of Applied Sciences (ISSN: 2314-6079) Vol. (6) Is. (3), Dec. 2017

Table (5). Effect of dietary Moringa oleifera seeds meal on economical evaluation of quail at 42 days old.

\begin{tabular}{ccccc}
\hline & & \multicolumn{3}{c}{ Moringa oleifera Seeds meal (\%) } \\
\cline { 3 - 5 } Item & & $\mathbf{0 . 2}$ & $\mathbf{0 . 4}$ & $\mathbf{0 . 6}$ \\
\hline Feed intake/ bird (g) & 0.554 & 0.598 & 0.567 & 0.529 \\
Final body weight (g) & 253.65 & 278.71 & 274.18 & 245.41 \\
Price/Kg feed (L.E)* & 4.62 & 4.69 & 4.76 & 4.84 \\
Price of K.g (L.E) ** & 28.00 & 28.00 & 28.00 & 28.00 \\
Cost of feed (L.E) & 2.56 & 2.80 & 2.70 & 2.56 \\
Fixed cost ( L.E) & 1.25 & 1.25 & 1.25 & 1.25 \\
Total cost (L.E) & 3.81 & 4.05 & 3.95 & 3.81 \\
Selling revenue (L.E) & 7.10 & 7.80 & 7.68 & 6.87 \\
Net revenue & 3.29 & 3.75 & 3.73 & 3.06 \\
Economic efficiency*** & 86.35 & 92.49 & 94.34 & 80.45 \\
Relative economic efficiency*** & 100 & 106.88 & 109.01 & 92.97 \\
\hline * Based on average price of diets during the experimental time. & & & \\
** According to the local market price at the experimental time. & & & \\
*** Net revenue per unit feed cost. \\
****Assuming economic efficiency of control group equals 100.
\end{tabular}

Atuahene, C.C.; Attoh-Kotoku, V.; Fosu, K.D.; Amissah, S.E.; Sarfo, F.K. and Mensah, J.J. (2010). Preliminary study of the effect of feeding Moringa oleifera leaf meal as a feed ingredient on the growth performance of broiler chickens. Proceedings of the $28^{\text {th }}$ and $29^{\text {th }}$ Ghana Animal Science Association held at the Univ. Education, Winneba, Mmpong Campus, $9^{\text {th }}$ Aug., 2008, 72-75.

Compaoré, W.R.; Nikièma, P.A.; Bassolé, H.I.N.; Savadogo, A.; Mouecoucou, J.; Hounhouigan, D.J. and Traoré, S.A. (2011). Chemical composition and antioxidative properties of seeds of Moringa oleifera and pulps of Parkiabiglobosa and Adansoniadigitata commonly used in food fortification in Burkina Faso, Current Res. J. Biol. Sci., 3 (1): 64-72.
Debela, E. and Tolera, A. (2013). Nutritive value of botanical fractions of Moringa oleifera and Moringa stenopetala grown in the mid-Rift Valley of south-ern Ethiopia. Agroforest. Syst. 87: 11471155.

Dey, A. and De, P.S. (2013) Influence of Moringa oleifera leaves as a functional feed additive on the growth performance, carcass characteristics and serum lipid profile of broiler chicken. Indian J. Anim. Res., 47 (5): 449.

Diallo, A.; Eklu-Gadegkeku, K.; Mobio, T.; Moukha, S.; Agbonon, A.; Aklikokou, K.; Creppy, E.E. and Gbeasso, M. (2009). Protective Effect of Moringa oleifera Lam. and Lanneakerstingii Extracts Against Cadmium and Ethanol-induced Lipid 
Peroxidation J. Pharmacolo. and Makanjuola, B.A.; Obi, O.O.; Toxicol., 4 (4): 160-166.

Duncan, D.B. (1955). Multiple Range and Multiple F-Tests. Biomettics, 11:1-42.

Durgesh, K.D., Jyotsun, D., Anil, K. and Retan, K.G. (2013). A Multipurpose tree Moringa oleifera. Int. J. Pharmaceutical and Chem. Sci., 2 (1): 165-171.

El-Badawi, A.Y.; Omer, H.A.A.; Abedo, A.A. and Yacout, M.H.M. (2014) Response .of growing new zealand white rabbits to rations supplemented with different levels of moringaoleifera dry leaves. Global Vet., 12 (4): 573-582.

El-Deeb, M.A.; Essa, N.M.; Younis, M. and Saleh, A.A. (2014). Utilization of Moringa (Moringa oleifera) Leaves Meal As A None-Traditional Feedstuff on Productive Performance of Broiler Chicks. 4th. Mediterranean Poultry Summit of the Mediterranean Poultry Network of the WPSA. September 2-5, 2014, Beirut, Lebanon. (Abs.)

Fahey, J.W.; Zakmann, A.T. and Talalay, P. (2001). The chemical diversity and distribution of glucosinolates and isothiocyanaes among plants. Corrigendum Phytochem., 59: 200-237.

Kout Elkloub E.L.; Shata, R.; Mousa, H.; Alghonimy, A.H. and Youssef, S.F. (2015). Effect of using Moringa oleifera leaf meal on performance of Japanese quail. Egypt. Poult. Sci., (35): 10951108.

Mahmud, M.A.; Peter, S.; James, G.; Ruth, N.; Wosilat, A.; Musa, M. and Abubakar, M.A. (2016). Growth Performance and Gastrointestinal Tract Morphometry in Growing Japanese Quails Fed with Moringa oleifera Leaf Meal as Partial Replacement of Dietary Soya Beans Meal. J. World Poult. Res., 6 (2): 92-98.

Olorungbohunmi, T.O.; Morakinyo, O.A.; Oladele-Bukola, M.O. and Boladuro, B.A. (2014). Effect of Moringa oleifera leaf meal as a substitute for antibiotics on the performance and blood parameters of broiler chickens. Livestock Res. Rural Develop., 26 (8).

Mousa, R.M.A.M.; Shata, F.H.; Kout Elkloub, Moustafa, M.El.; Youssed, S.F. and Alghonimy, H.A.H. (2016). Effect of using germinated Moringa oleifera seeds on Japanese quail growth performance. Egypt. Poult. Sci., 36 (2): 561-571.

NRC (1994). National Research Council. Nutrient Requirements of Rabbits. Washington, DC. USA.

Ochi, E.B.; Elbushra, M.E.; Fatur, M.; Abubakr, O. and Ismail, H.A. (2015). Effect of Moringa (Moringa oleifera Lam) Seeds on The Performance and Carcass Characteristics of Broiler Chickens. J. Nat. sci. Res., 5 (8): 66-73.

Olaniyan, O.M. (2012). Nutrigenetic effects of Moringa oleifera Seed Meal on young broiler chickens B. Agric project, submitted to Dept. Anim. Prod. Univ. Ilorin, 45-48.

Paguia, H.M.; Paguia, R.Q.; Flores, R.C. and Balba, C.M. (2014). Utilization and evaluation of Moringa oleifera as poultry feeds. Monograph No. 11. The Research and Development Office, Bataan Peninsula State Univ. City of Balanga, Philippines.

Rocha, J.S.R.; Lara, L.J.C.; Baiao, N.C.; Vasconcelos, R.J.C.; Barbosa, V.M.; Pompeu, M.A. and Fernandes, M.N.S. (2010). Antioxidant properties of vitamins in nutrition of broiler breeders and laying hens. World's Poult. Sci. J., 66: 261-270. 
SAS Institute Inc. (2004). SAS procedures Guide for personal Computers, Statistical Analysis System Institute, Inc., Cary, NC.

Shata, R.F.H.; Kout Elkloub, M.; Moustafa, E.L.; Mousa, M.A.M.; Youssef, S.F. and Alghonimy, H.A.H. (2016). Effect of using moringaoleifera seed meal on japanese quail performance during growing period. $9^{\text {th }}$ International
Poultry Conference - Proceeding. $7-10^{\text {th }}$ Nov. 2016, Hurghada, Red Sea-Egypt.

Toye, A.A.; Sola-Ojo, F.E.; Olaniyan, O.M. and Ojo, V. (2013). Nutrigenetic effect of Moringa oleifera seed meal on the biological growth programme of young broiler chickens. AGROSEARCH (Special Moringa (Edition), 3 (1): 149163. 


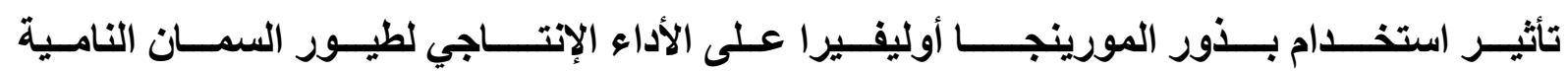

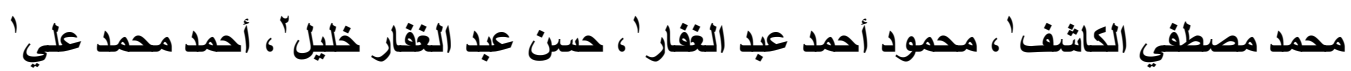

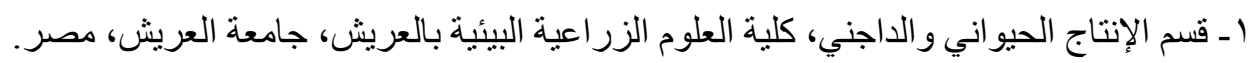

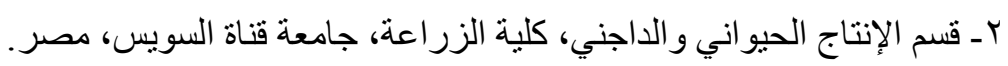

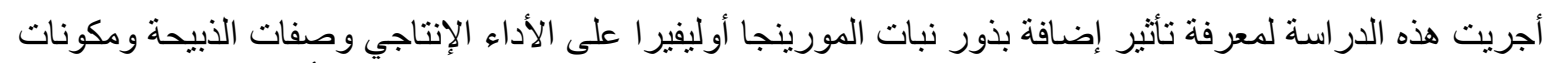

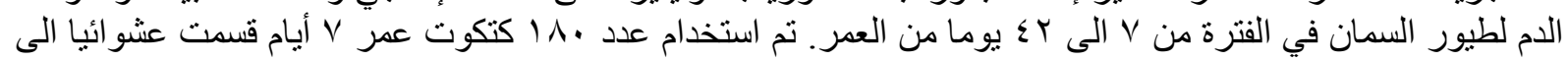

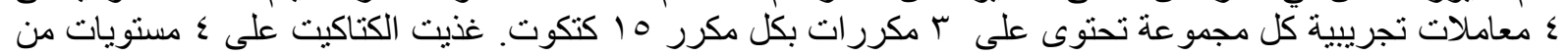

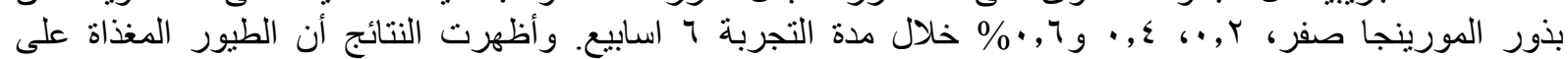

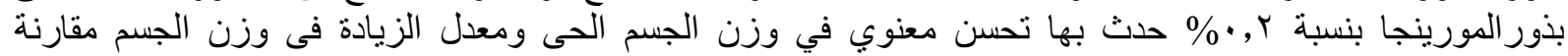

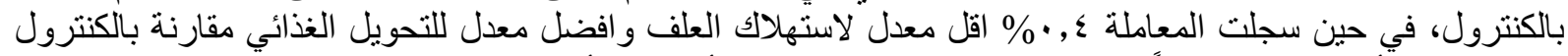

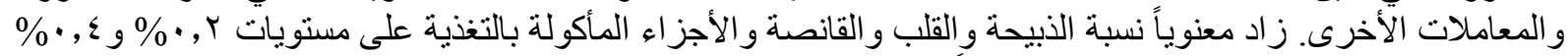

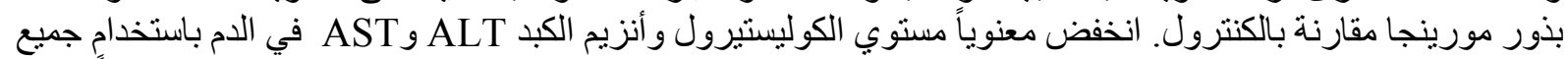

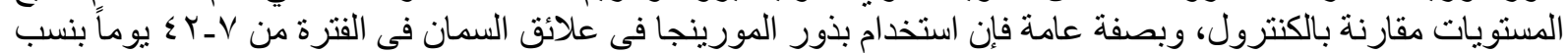

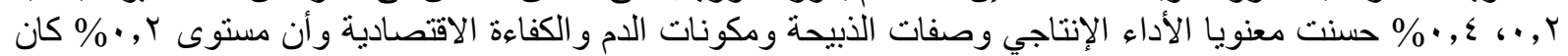
أفضلها. الكلمات الإسترشادية: مسحوق بذور المورينجا أوليفيرا، الأداء الإنتاجي، السمان، ظروف شمال سيناء.

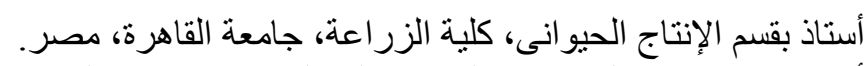
أستاذ بقسم الإنتاج الحيو النى والدواجئ كلية الزراعة كلية الزر اعة، جامعة القاهرة، مصرة.

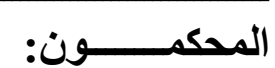

ا ـ أ.د. ممدوح عمر عبدالسميع

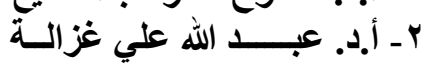

